\title{
Constructive Capitalization of Operating Leases in the Hong Kong Fast-Food Industry
}

\author{
Benjamin Y. Tai \\ Department of Accountancy, California State University, Fresno \\ 5245 N. Backer Ave., Fresno, CA 93740, U.S.A \\ Tel: 11-559-278-2217_Email: benjamin@csufresno.edu
}

Received: February 16, 2013 Accepted: March 14, 2013 DOI: 10.5296/ijafr.v3i1.3270

\begin{abstract}
The current study is undertaken to investigate the potential problems resulting from the proposed adoption of a new accounting standard concerning mandatory capitalization of all lease contracts. In 2010, the International Accounting Standards Board (IASB) and the Financial Accounting Standards Board (FASB) issued a joint exposure draft (ED2010/9) on accounting for leases. Under the new standard, lessees are required to capitalize all lease contracts as assets and liabilities. The distinction between operating leases and capital (finance) leases will no longer exist. The long-standing off-balance sheet treatment of operating leases will be prohibited. After the adoption of the proposed standard, companies with significant operating leases are likely to experience an increase in assets, increase in liabilities, and decrease in equity, resulting in the deterioration of their return-on- assets and debt-to-equity ratios. This research examines two large fast-food restaurant chains based in Hong Kong; and through constructive capitalization, demonstrates how the companies' key financial ratios are negatively impacted if the new standard is implemented. The results indicate that both the return-on-assets and debt-to-equity ratios of the two companies, under various discount rates assumptions, suffer serious deterioration when their operating leases are capitalized.
\end{abstract}

Keywords: Constructive capitalization, operating leases, minimum lease payments 


\section{Mll Macrothink}

International Journal of Accounting and Financial Reporting

ISSN 2162-3082

2013, Vol. 3, No. 1

\section{Introduction}

Accounting for leases has been a controversial issue for decades among academics, standard setters, corporate management, and financial statements users. The current guidance of accounting for leases is found in Financial Accounting Standards Board's Statement No. 13, Accounting for Leases, issued in 1976. Non-cancellable leases that meet one or more of the following four criteria must be capitalized by the lessees: (1) there is a transfer of ownership of the lease asset from the lessor to the lessee at the end of the lease term, (2) there is a "bargain purchase option," (3) the length of the lease term is $75 \%$ or more of the asset's expected economic life, or (4) the present value of minimum future lease payments is $90 \%$ or more of the asset's fair value at the inception of the lease agreement.

Internationally, the International Accounting Standards Board (formerly International Accounting Standards Committee) issued IAS 17, Leases, in 1982 which requires the lessees to recognize both an asset and a liability for a lease that transfers substantially all risks and rewards incidental to the ownership of the asset. Even though the two standard-setting bodies differ in their specific requirements, they both adopt the "ownership" approach in deciding whether a lease contract should be capitalized.

Over the years, companies have strived to structure most lease contracts to bypass the capitalization criteria so that capitalization of assets and liabilities on the balance sheets are not required. In the United States, this is achieved by circumventing any one of the four bright-line criteria that triggers capitalization. Avoiding these criteria will keep the lease asset and obligation off the lessee's balance sheet, thereby improving financial ratios, lowering cost of capital, and boosting executive compensation.

According to the World Leasing Yearbook 2010, quoted by the IASB (2010), leasing activity in 2008 amounted to $\$ 640$ billion, while the assets and liabilities arising from many of those contracts are not capitalized on the lessees' statements of financial position (balance sheets). The 2005 SEC Report (SEC 2005) reveals an estimated amount of $\$ 1.25$ trillion of undiscounted total non-cancellable future payments required under operating leases for U.S. companies.

In 1996, the G4+1 Group (consisting of accounting standard-setting bodies of Australia, Canada, New Zealand, United Kingdom, and the United States, plus the International Accounting Standards Committee) issued a special report in which it proposed a single lease accounting method to eliminate the distinction between operating and capital leases and recognize an asset and a liability equivalent to the fair value of the rights and obligations conveyed by the lease. In 2000, the G4+1 Group further released a discussion paper developing the views in the original report. It proposed the replacement of the current "substantially all risks and rewards" approach by an "asset and liability" approach, and all lease contracts should create an asset and liability for the lessees.

On August 17, 2010, the International Accounting Standards Board (IASB) and the Financial Accounting Standards Board (FASB) issued a joint exposure draft (ED2010/9) on accounting for leases. The document provides a new accounting model for both the lessees and lessors. 


\section{Al Macrothink}

International Journal of Accounting and Financial Reporting ISSN 2162-3082 2013, Vol. 3, No. 1

The new proposal consists of a "right-of-use" accounting model to substitute for the "ownership" model, where the lessees recognize assets and liabilities arising from all lease contracts. These assets and liabilities would be initially measured at the present value of future lease payments. They would be subsequently measured using a cost-based method.

The current consensus for lease accounting appears to be capitalization of all lease contracts at their inception, regardless of their terms and conditions. Off-balance sheet treatment of leases will no longer be allowed if the proposal is formally adopted. Comments and feedback on the exposure draft collected during the past two years have been generally supportive. Adoption of the new standard is expected to occur in the near future for companies that follow U.S. or IASB accounting standards.

In Hong Kong, companies are required to prepare financial statements in accordance with the Hong Kong Financial Reporting Standards (HKFRSs), which follow the IASB standards. Hong Kong Accounting Standards (HKAS) 17, Leases, provides authoritative guidance in accounting for leases for both the lessors and lessees. The requirements of HKAS 17 Leases are virtually identical to IAS 17 Leases.

Hong Kong's situation is unique in several aspects. First, property prices in Hong Kong are known to be notoriously high. Rent/lease expenses usually account for a significant portion of normal operating expenses for many retail businesses. With the low interest rate environment worldwide, discounting large amounts of future lease payments to present value using a low discount rate will result in huge lease liabilities and assets if the leases are capitalized. As a result, there is strong incentive for managers to treat leases as operating leases whenever possible. Second, Hong Kong companies are traditionally more conservative in using debt as a means of financing. The typical debt-to-equity ratios are low compared to their counterparts in the United States and Europe. Capitalization of leases means an increase in assets, increase in debt and decrease in equity, resulting in significant plunge in the return-on-assets and surge in the debt-to-equity ratios. In the likely event that the new IASB/FASB standard on lease accounting will be adopted in the near future, how should Hong Kong companies prepare themselves to face the possible fatal blow caused by the sudden deterioration of their financial ratios?

\section{Literature Review}

Early work of Imhoff, Lipe, and Wright (1991) suggests that capitalization of operating leases have a significant effect on the risk and return measures such as the accounting ratios. To enhance the relevance and comparability of these measures, they proposed a constructive capitalization method of treating long-term operating lease commitments so an asset and liability will be recorded on the balance sheet of the lessees. Using their method to estimate how capitalizing operating leases would affect a small sample of U.S. companies, they found that in fiscal 1987, if they had capitalized the operating lease commitments disclosed in footnotes, the 14 U.S. companies (seven industry pairings) examined would have experienced: (a) an average $34 \%$ decrease in return-on-assets for high lessees and $10 \%$ for low lessees, and (b) an average $191 \%$ increase in the debt-to-equity ratio for high lessees and $47 \%$ for low lessees. In a later study, Imhoff et al. (1997) constructively capitalized operating leases using 
the same assumptions by estimating the present value of operating leases for a sample of 29 airlines and 51 grocery stores for fiscal years 1984-89. They obtained a mean percentage increase in the debt-to-assets ratio of $16.2 \%$ for airlines and $15.9 \%$ for grocery stores.

Using simplified assumptions, Gritta, Lippman, and Chow (1994) calculated the effect of capitalizing operating leases on the debt burden of U.S. airlines. They applied a uniform $10 \%$ interest rate to discount future lease payments. The debt-to-capital ratio increased from $21.8 \%$ to $60.7 \%$ for six of the ten firms in 1991 .

In a similar study of 126 U.S. companies in nine industry segments reporting in fiscal 1998, Gosman and Hanson (2000) assumed that the present value of minimum lease payments (PVMLP) equaled 50\% of the total lease payments disclosed in the footnote. The resulting median debt-to-capitalization (interest-bearing debt/shareholders' equity) ratio increased from $35 \%$ to $56 \%$. After capitalizing operating leases, the leverage ratios of 30 sample firms exceeded $50 \%$, with ten firms reporting over $75 \%$.

Duke and Hsieh (2006) used Imhoff et al.'s $(1991,1997)$ assumptions to compute the effect of capitalizing the operating leases of six U.S. firms that The Wall Street Journal identified as significant users of off-balance-sheet lease financing. Assuming a uniform 10\% interest rate, a remaining life of 15 years, and an unamortized asset of $70 \%$ of unrecorded liability, they calculated a mean off-balance-sheet liability of $89.5 \%$ of total unadjusted liabilities and a mean unrecorded asset of $39.4 \%$ of total unadjusted assets.

More recently, Bryan, Lilien, and Martin (2010) examined Walgrens' 2008 10-K financial reports, and performed constructive capitalization of the company's operating leases. They found that the return-on-assets ratio decreased by $43.8 \%$ and the debt-to-equity ratio increased by $503.0 \%$. They also studied 8 industries and performed similar constructive capitalization, and found that the most drastic change occurred in the retail industry, with the return-on-assets ratio decreased by an average of $30.0 \%$ and debt-to-equity ratio increased by an average of $75.7 \%$.

In the United Kingdom, Beattie, Edwards, and Goodacre (1998) adapted the Imhoff et al. (1991) method and computed the average total and remaining lease life by asset type and expiry date for 13 cases of seven U.K. companies between 1987 and 1995 . Using a uniform interest rate of $10 \%$ corresponding to the mean three-month London deposit rate from 1988 to 1994, they found that the unrecorded operating lease liability was $39 \%$ of the reported long-term debt and the debt-to-equity ratio would increase by $260 \%$.

Examining the impact of constructively capitalizing operating leases on 38 New Zealand firms for fiscal 1995, Bennett and Bradbury (2003) used a 9.4\% interest rate to discount future cash flows. They assumed a total lease life of 10 years, $50 \%$ expired, an unamortized asset equal to $81 \%$ of the PVMLP, and a statutory tax rate of $33 \%$. The result was a $23 \%$ average increase in total liabilities and an $11 \%$ average increase in leverage ratio.

Lanfranconi and Wiedman (2000) used simplified assumptions to compute the impact of the G4 +1 proposals on ten large Canadian companies in the retail and hospitality industries. They assumed a uniform $8.5 \%$ interest rate to discount future lease payments, but did not 
consider any tax effect or effect on net income. Their results showed that capitalizing the firms' operating leases increased the long-term debt of eight of the ten companies by more than 50\% for the years ending between December 31, 1998 and April 30, 1999. Operating lease capitalization also increased the reported capital assets of eight of the ten companies by more than $35 \%$.

Using the 100 largest Canadian public companies (by revenue) in the sample, Durocher (2008) developed a refined approach for assessing the impact of operating lease capitalization that incorporates company-specific assumptions to restate reported figures. The results revealed that the mean debt-to-asset ratio increased from $66.2 \%$ to $68.9 \%$. The difference is significant at the $1 \%$ level. However, return-on-assets, return-on-equity, and earnings-per-share ratios were found to be insignificantly different.

\section{Research Methodology and Results}

In this study, two Hong Kong-based fast food restaurant chains, namely, Fairwood Holdings Limited (Fairwood) and Café de Coral Holdings Limited (CDC) were selected for analysis. Fairwood has a total of 108 restaurants in operation in Hong Kong and 19 in Mainland China as of March 31, 2012, with total sales of HK\$1,829.5 million (US\$1.00 $=\mathrm{HK} \$ 7.75$ ). On the other hand, CDC has a total of 207 restaurants in Hong Kong, 106 in Mainland China, and 280 in other countries, with total sales of $\mathrm{HK} \$ 5,956.4$ million. Both companies heavily relied on leasing as a means of financing their physical facilities. These leases were accounted for as operating leases since no long-term lease liabilities were reported on their balance sheets during the period of study (2008-12).

From the two companies' websites, annual audited financial statements and relevant footnotes for the period from 2008 to 2012 were retrieved. Both companies have a fiscal year end of March 31. From the footnotes of the financial statements, minimum future lease payments for each of the next five years, plus the total amount from years six through ten, were obtained. In addition, total assets, total liabilities, total equity, total profit, and tax rate were acquired from the March 31, 2008 financial statements. Tables 1A and 1B show these data for Fairwood and CDC respectively.

Table 1A Fairwood Holdings Limited - Selected Financial Statements and Footnote Data

\begin{tabular}{|l|c|}
\hline Minimum Lease Payments for Year & $\$ ’ 000$ \\
\hline 2008 & 166,014 \\
\hline 2009 & 172,706 \\
\hline 2010 & 199,830 \\
\hline 2011 & 218,348 \\
\hline 2012 & 240,275 \\
\hline $2013-2017$ total & 57,565 \\
\hline Total & $1,054,738$ \\
\hline
\end{tabular}




\begin{tabular}{|l|c|}
\hline From Financial Statements as of March 31, 2008 & $\$ 000$ \\
\hline Reported total assets & 625,277 \\
\hline Reported total liabilities & 255,324 \\
\hline Reported total equity & 369,953 \\
\hline Reported profit & 101,027 \\
\hline Reported tax rate & $16 \%$ \\
\hline
\end{tabular}

Table 1B Café de Coral Holdings Limited - Selected Financial Statements and Footnote Data

\begin{tabular}{|l|r|}
\hline Minimum Lease Payments for Year & HK\$'000 \\
\hline 2008 & 468,229 \\
\hline 2009 & 464,095 \\
\hline 2010 & 431,395 \\
\hline 2011 & 540,515 \\
\hline 2012 & 557,796 \\
\hline $2013-2017$ total & 928,313 \\
\hline Total & $3,390,343$ \\
\hline
\end{tabular}

\begin{tabular}{|l|c|}
\hline From Financial Statements as of March 31,2008 & HK\$'000 \\
\hline Reported total assets & $2,934,496$ \\
\hline Reported total liabilities & 547,108 \\
\hline Reported Equity & $2,387,388$ \\
\hline Reported profit & 420,234 \\
\hline Reported tax rate & $16 \%$ \\
\hline
\end{tabular}

\subsection{Estimating Unrecorded Liabilities and Unrecorded Assets}

The minimum lease payments for the future five-year period (2013-2017) for each company were relatively small since many lease contracts may expire within this period. As renewals are expected, this study follows the methodology used by Bryan, Lilien and Martin (2010), and assumed that the 2012 minimum lease payments will continue into each of the next five years. These figures are reported in Tables $2 \mathrm{~A}$ and $2 \mathrm{~B}$.

According to both U.S. and IASB accounting standards regarding capitalization of leases, lessees are required to discount their minimum future lease payments using their incremental borrowing rates. Since these rates were not disclosed in the financial statements, the prime rate was used to approximate the incremental borrowing rate. As of March 31, 2008, the Hong Kong prime rate was $5.75 \%$. A rounded and more conservative $6 \%$ was used as a discount rate for both companies in this study.

Using minimum lease payments and estimated incremental borrowing rates, results of the estimated lease liability of Fairwood and CDC are shown in Tables 2A and 2B respectively. The results reveal, when operating leases are capitalized, long-term liabilities of Fairwood and CDC would increase by $\mathrm{HK} \$ 1,586,928,000$ and $\mathrm{HK} \$ 3,817,728,000$ respectively. 


\section{Ml Macrothink}

International Journal of Accounting and Financial Reporting ISSN 2162-3082

Table 2A Present Value of Fairwood Holdings Limited's Operating Leases (HK\$ in thousands)

\begin{tabular}{|c|c|c|c|c|c|c|}
\hline & $\begin{array}{l}\text { Minimum } \\
\text { Lease } \\
\text { Payments* }\end{array}$ & $\mathrm{x}$ & $\begin{array}{l}6 \% \text { Present } \\
\text { Value Factor }\end{array}$ & $=$ & \multicolumn{2}{|c|}{$\begin{array}{c}\text { Present Value of } \\
\text { Cash Outflows }\end{array}$} \\
\hline 2008 & $\$ 166,014$ & $\mathrm{x}$ & 0.9434 & $=$ & \multirow[t]{6}{*}{$\$$} & 156,618 \\
\hline 2009 & 172,706 & $\mathrm{x}$ & 0.8900 & $=$ & & 153,708 \\
\hline 2010 & 199,830 & $\mathrm{x}$ & 0.8396 & $=$ & & 167,777 \\
\hline 2011 & 218,348 & $\mathrm{x}$ & 0.7921 & $=$ & & 172,954 \\
\hline 2012 & 240,275 & $\mathrm{x}$ & 0.7473 & $=$ & & 179,558 \\
\hline \multirow{2}{*}{$\begin{array}{l}2012 \text { to } 2017 \\
\text { (per year) }\end{array}$} & 240,275 & $\mathrm{x}$ & $3.1477^{\circ}$ & $=$ & & 756,314 \\
\hline & & \multicolumn{3}{|c|}{ Estimated unrecorded debt } & \multicolumn{2}{|c|}{$\$ 1,586,928$} \\
\hline
\end{tabular}

*Rounded to the nearest $\mathrm{HK} \$ 1,000$ and assumed all payments occur at the year end.

${ }^{\circ}$ Present value of a 10-year ordinary annuity at $6 \%$ minus the present value of a 5 -year ordinary annuity at $6 \%$

Table 2B Present Value of Café de Coral Holdings Limited's Operating Leases (HK\$ in thousands)

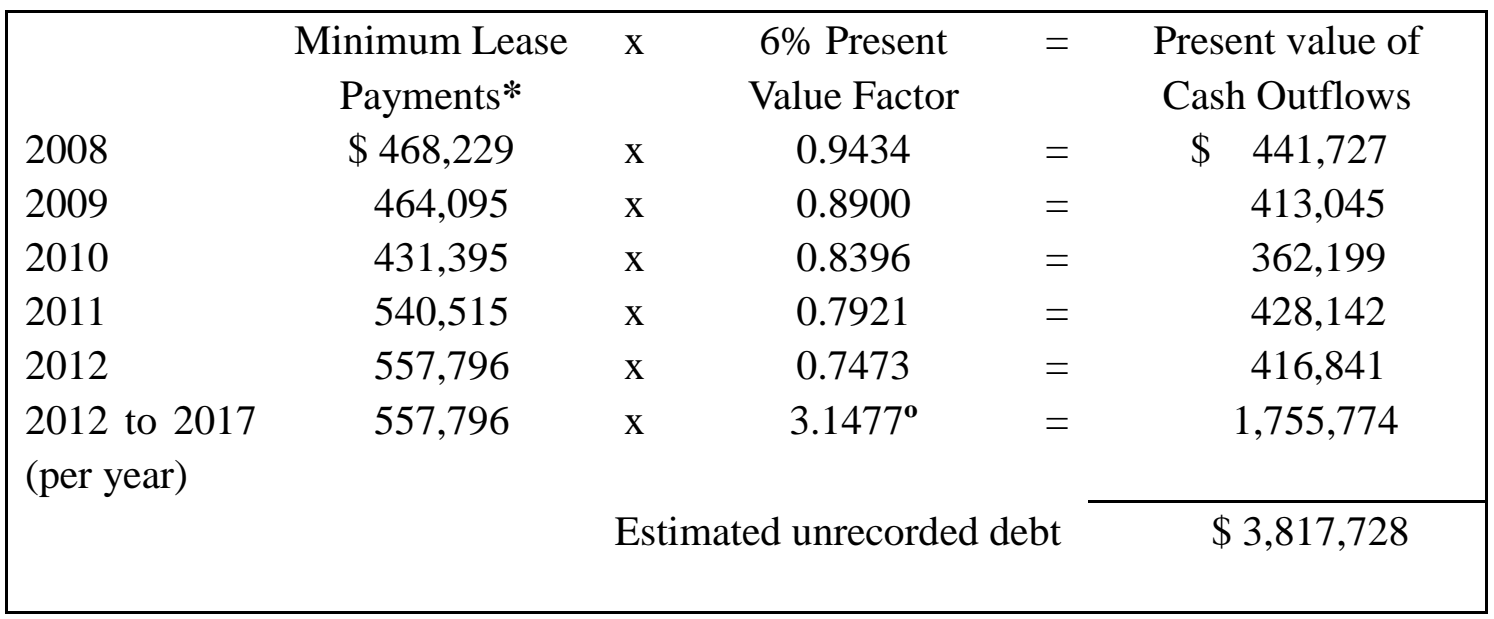

*Rounded to the nearest HK\$1,000 and assumed all payments occur at the year end.

${ }^{\circ}$ Present value of a 10 -year ordinary annuity at $6 \%$ minus present value of a 5 -year ordinary annuity at $6 \%$.

Table 3 shows how unrecorded asset is estimated after estimating the unrecorded liability. Certain assumptions are used when constructing this table. First, the straight-line depreciation method is assumed for all assets and capitalized leases are amortized evenly. In addition, both the unrecorded asset and liability equals $100 \%$ of the present value of the minimum future lease payments at the beginning of each lease and they are both zero after the last payment is made for each lease. 


\section{Mll Macrothink}

When a lease is capitalized, a lease liability and a lease asset are created. Since lease liabilities were estimated in Tables $2 \mathrm{~A}$ and $2 \mathrm{~B}$, Table 3 was constructed to estimate the relationship between lease liabilities and lease assets in order to estimate the magnitude of the lease assets. By assuming total lease periods of 6, 8, 10 and 12 years and marginal interest rates of $4 \%, 6 \%$ and $8 \%$, Table 3 shows the ratios of the asset balance to the liability balance at different points of an asset's life. Following the procedures of Imhoff et al. (1991), the average lease period of 10 years with a $40 \%$ lease life expired (85\%) and lease period of 12 years with a 50\% lease life expired (79\%) was used to approximate the ratio of asset balance to liability balance. As a result, the average ratio is $82 \%[(85 \%+79 \%) / 2]$.

As unrecorded lease assets are estimated at $82 \%$ of unrecorded lease liabilities, the difference between unrecorded lease liabilities and unrecorded lease assets (18\%) represents additional lease expenses. With a corporate income tax rate of $16 \%$ in effect in Hong Kong, the after-tax effect on net income and retained earnings is reduced. The reduction of retained earnings and stockholders' equity was then computed. The results are shown in Tables 4A and 4B. 


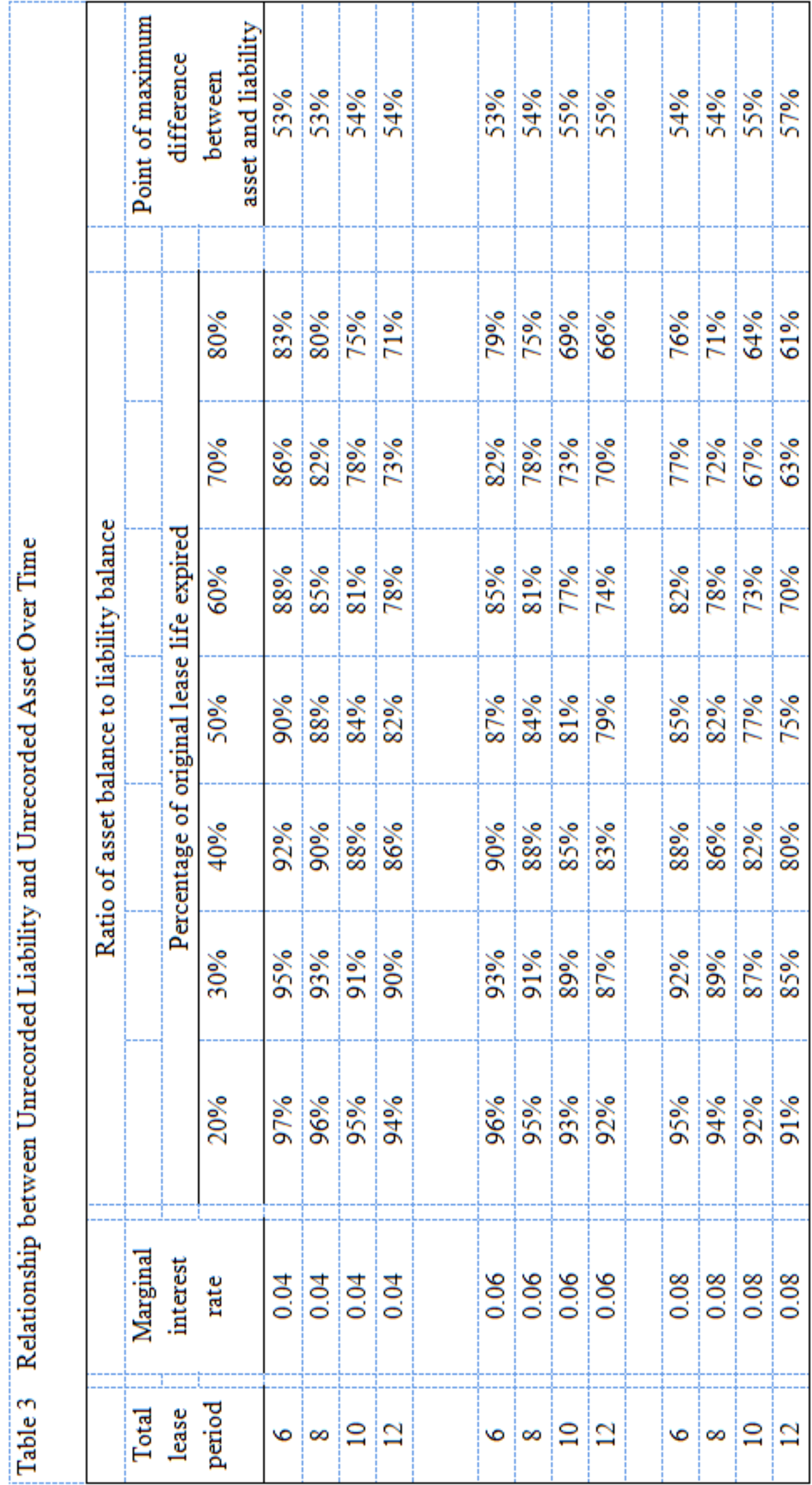




\section{1) Macrothink}

International Journal of Accounting and Financial Reporting

ISSN 2162-3082 2013, Vol. 3, No. 1

Table 4A Impact of Constructive Capitalization on Fairwood Holdings Limited's Balance Sheet

Balance Sheet

March 31, 2008

(HK\$ in thousands)

Assets:

Unrecorded Lease Assets $\quad 1,301,281$

$1,301,281$

\begin{tabular}{|lc} 
Liabilities: & \\
Unrecorded Lease Liabilities & $1,586,928$ \\
Tax Deductions & \\
$(1,586,928-1,301,281) \times 16 \%$ & $\frac{(45,704)}{1,541,224}$ \\
Net Liability Effect & \\
Stockholders' Equity: & \\
Cumulative Effect on Retained & \\
Earnings net of tax deductions & $\frac{(239,943)}{1,301,281}$ \\
\hline
\end{tabular}

Table 4B Impact of Constructive Capitalization on Café de Coral Holdings Limited's Balance Sheet

Balance Sheet

March 31, 2008

(HK\$ in thousands)

\begin{tabular}{|c|c|c|c|}
\hline Assets: & & Liabilities: & \\
\hline Unrecorded Lease Assets & $3,130,537$ & Unrecorded Lease Liabilities & $3,817,728$ \\
\hline & & $\begin{array}{l}\text { Tax Deductions } \\
(3,817,728-3,130,537) \times 16 \%\end{array}$ & $(109,951)$ \\
\hline & & Net Liability Effect & $3,707,777$ \\
\hline & & Stockholders' Equity: & \\
\hline & & Cumulative Effect on Retained & \\
\hline & & Earnings net of tax deductions & $(577,240)$ \\
\hline & $3,130,537$ & & $3,130,537$ \\
\hline
\end{tabular}

\subsection{Sensitivity Analysis and Impact on Key Financial Ratios}

The discount rate used in the analysis was $6 \%$, slightly higher than the prime rate $(5.75 \%)$ at the time when the capitalization is assumed to take place. To be on the conservative side, a sensitivity analysis was performed to examine the potential impact of constructive capitalization on the magnitude of unrecorded lease liabilities and the resulting financial ratios. Tables $5 \mathrm{~A}$ and $5 \mathrm{~B}$ show various amount of estimated unrecorded debts when the discount rates are set at $7 \%, 8 \%, 9 \%$, and $10 \%$.

Table 5A Sensitivity Analysis on Estimated Unrecorded Debts of Fairwood Holdings Limited (HK\$ in thousands) 


\begin{tabular}{|l|c|}
\hline Assumption as above except: & Estimated unrecorded debts \\
\hline If interest rate is $7 \%$ & $\$ 1,558,593$ \\
If interest rate is $8 \%$ & $\$ 1,489,574$ \\
If interest rate is $9 \%$ & $\$ 1,424,870$ \\
If interest rate is $10 \%$ & $\$ 1,307,675$ \\
\hline
\end{tabular}

Table 5B Sensitivity Analysis on Estimated Unrecorded Debt of Café de Coral Holdings Limited (HK\$ in thousands)

\begin{tabular}{|l|c|}
\hline Assumption as above except: & Estimated unrecorded debts \\
\hline If interest rate is $7 \%$ & $\$ 3,749,948$ \\
If interest rate is $8 \%$ & $\$ 3,587,777$ \\
If interest rate is $9 \%$ & $\$ 3,435,678$ \\
If interest rate is $10 \%$ & $\$ 3,161,796$ \\
\hline
\end{tabular}

Tables $6 \mathrm{~A}$ and $6 \mathrm{~B}$ show the original return-on-assets and debt-to-equity ratios based on numbers actually reported on the 2008 financial statements when the operating leases were not capitalized. The tables also show the new ratios when future lease payments were constructively capitalized at discount rates of $6 \%, 8 \%$ and $10 \%$. The differences between each newly computed ratio and the original ratio were exhibited. The results are astonishing. For Fairwood, when future lease payments were discounted at a $6 \%$ rate, the return-on-assets ratio dropped from $16.2 \%$ to $5.2 \%$ (a $67.9 \%$ decrease) while the debt-to-equity ratio rose from 0.69 times to 14.17 times (a 1,953.6\% increase). The magnitude of the changes is extremely significant when compared with results of prior studies. For CDC, when future lease payments were discounted at $6 \%$, the return-on-assets ratio dropped from $14.3 \%$ to $6.9 \%$ (a $51.2 \%$ decrease) while the debt-to-equity ratio rose from 0.23 times to 2.41 times (a 947.8\% increase). The change in CDC's ratios is less drastic compared to Fairwood's.

The two tables also show the results when the more conservative $8 \%$ and $10 \%$ discount rates were employed to constructively capitalize future lease payments. As anticipated, the drop in the return-on-assets and rise in the debt-to-equity ratios were less severe but still very significant. For Fairwood, the decrease in return-on-assets ratio is $66.0 \%$ for the $8 \%$ discount rate and $62.9 \%$ for the $10 \%$ discount rate, while the increase in debt-to-equity ratio is $1,650.7 \%$ for the $8 \%$ discount rate and $1,614.5 \%$ for the $10 \%$ discount rate. For CDC, the decrease in return-on-assets ratio is $49.7 \%$ for the $8 \%$ discount rate and $46.9 \%$ for the $10 \%$ discount rate, while the increase in debt-to-equity ratio is $873.9 \%$ for the $8 \%$ discount rate and $743.5 \%$ for the $10 \%$ discount rate. The impact of constructive capitalization appears to be much more serious to Fairwood than CDC.

Table 6A Impact of Constructive Capitalization on Fairwood Holdings Limited's Financial Ratios (numbers in parentheses represent $\mathrm{HK} \$$ in thousands) 


\begin{tabular}{|c|c|c|}
\hline & Return-on-Assets & Debt-to-Equity \\
\hline $\begin{array}{l}\text { As reported on annual } \\
\text { reports }\end{array}$ & $\begin{array}{c}16.2 \% \\
(101,027 / 625,277) \\
\end{array}$ & $\begin{array}{c}0.69 \text { times } \\
(255,324 / 369,953) \\
\end{array}$ \\
\hline $\begin{array}{l}\text { Adjusted by capitalization } \\
\text { (interest rate of 6\%) } \\
\text { Difference }\end{array}$ & $\begin{array}{c}5.2 \% \\
(101,027 / 1,926,558) \\
67.9 \% \text { decrease } \\
\end{array}$ & $\begin{array}{c}14.17 \text { times } \\
(1,842,252 / 130,010) \\
1,953.6 \% \text { increase } \\
\end{array}$ \\
\hline $\begin{array}{l}\text { Adjusted by capitalization } \\
\text { (interest rate of } 8 \% \text { ) } \\
\text { Difference }\end{array}$ & $\begin{array}{c}5.5 \% \\
(101,027 / 1,846,422) \\
66.0 \% \text { decrease } \\
\end{array}$ & $\begin{array}{c}12.08 \text { times } \\
(1,744,898 / 144,473) \\
1,650.7 \% \text { increase } \\
\end{array}$ \\
\hline $\begin{array}{l}\text { Adjusted by capitalization } \\
\text { (interest rate of } 10 \% \text { ) } \\
\text { Difference }\end{array}$ & $\begin{array}{c}6.0 \% \\
(101,027 / 1,697,571) \\
62.9 \% \text { decrease }\end{array}$ & $\begin{array}{c}9.07 \text { times } \\
(1,562,999 / 172,233) \\
1,214.5 \% \text { increase }\end{array}$ \\
\hline
\end{tabular}

Table 6B Impact of Constructive Capitalization on Café de Coral Holdings Limited's Financial Ratios (numbers in parentheses represent $\mathrm{HK} \$$ in thousands)

\begin{tabular}{|l|c|c|}
\cline { 2 - 3 } \multicolumn{1}{c|}{} & Return-on-Assets & Debt-to-Equity \\
\hline $\begin{array}{l}\text { As reported on annual } \\
\text { reports }\end{array}$ & $14.3 \%$ & 0.23 times \\
& $(420,234 / 2,934,496)$ & $(547,108 / 2,387,388)$ \\
\hline $\begin{array}{l}\text { Adjusted by capitalization } \\
\text { (interest rate of } 6 \%)\end{array}$ & $6.9 \%$ & 2.41 times \\
Difference & $(420,234 / 6,065,033)$ & $(4,364,836 / 1,810,148)$ \\
& $51.2 \%$ decrease & $947.8 \%$ increase \\
\hline $\begin{array}{l}\text { Adjusted by capitalization } \\
\text { (interest rate of } 8 \%)\end{array}$ & $7.2 \%$ & 2.24 times \\
Difference & $420,234 / 5,876,473)$ & $(4,134,885 / 1,844,916)$ \\
\hline & & $873.9 \%$ increase \\
\hline $\begin{array}{l}\text { Adjusted by capitalization } \\
\text { (interest rate of } 10 \%)\end{array}$ & $(420,234 / 5,527,169)$ & $(3,708,904 / 1,909,325)$ \\
Difference & $46.9 \%$ decrease & $743.5 \%$ increase \\
\hline
\end{tabular}

\section{Research Implications and Recommendation}

The Exposure Draft of the joint IASB/FASB Group (2010) proposed a new rule of accounting for leases for both the lessors and lessees. For lessees, all leases, regardless of terms and conditions, must be capitalized. Keeping operating leases off the balance sheet will no longer be acceptable. Thus far, comments and feedback received from respondents of the exposure draft are generally favorable. Adoption of the new standard in the near future is expected. The adoption will significantly affect financial ratios of U.S. companies currently having substantial operating leases as well as companies located in countries that follow the IASB standards, including Hong Kong. 


\section{Mll Macrothink}

International Journal of Accounting and Financial Reporting ISSN 2162-3082 2013, Vol. 3, No. 1

As the research results indicate, the two major fast-food restaurant chains in Hong Kong will experience significant adverse effect resulting from deteriorating return-on-assets and debt-to-equity ratios when their long-term leases are capitalized. This potentially devastating consequence could reflect negatively on the companies' stock prices, cost of capital, executive compensation, and even their ability to carry on as a going concern.

While the adoption of the proposed standard with capitalization of all long-term lease commitments "enhances the relevance and comparability of firm-specific measures of risk and performance" (Imhoff, et al. 1991, p.51), the conceptual merit of the proposed standard should be supported. Unfortunately, companies worldwide must come up with practical strategies and measures to deal with the potential blow associated with the adoption of the new standard. As the results of the current study suggest, the issue is urgent and vital, and the consequence of the potential crisis should not be underestimated.

\section{Reference}

Beattie, V., Edwards, K., and Goodacre, A. (1998). The Impact of Constructive Operating Lease Capitalisation on Key Accounting Ratios. Accounting and Business Research 28 (4): 233-54.

Bennett, B., and Bradbury, M. (2003). Capitalizing Non-Cancelable Operating Leases. Journal of International Financial Management and Accounting 14 (2): 101-14.

Biondi, Y., Bloomfield, R., Glover, J., Jamal, K., Ohlson, J., Penman, S., Tsujiyama, E., and Wilks, T. (2011). A Perspective on the Joint IASB/FASB Exposure Draft on Accounting for Leases. Accounting Horizons 25 (4): 861-871.

Bryan, S., Lilien, S., and Martin, D. (2010). The Financial Statement Effects of Capitalizing Operating Leases: Assessing the Impact of the Right-of-Use Model. The CPA Journal August: 36-41.

Dhaliwal, D., Lee, H., and Niamtiu, M. (2011). The Impact of Operating Leases on Firm Financial and Operating Risk. Journal of Accounting, Auditing \& Finance 26 (2): 151-197.

Duke, J., Franz, D., and Hsieh, S. (2012). Evaluating Constructive Lease Capitalization and Off-Balance-Sheet Financing: An Instructional Case with FedEx and UPS. Accounting Perspectives 11 (1): 57-69.

Duke, J., and Hsieh, S. (2006). Capturing the Benefits of Operating and Synthetic Leases. Journal of Corporate Accounting \& Finance 18 (1): 45-52.

Durocher, S. (2008). Canadian Evidence on the Constructive Capitalization of Operating Leases. Accounting Perspectives 7 (3): 227-256

Durocher, S. and Fortin, A. (2009). Proposed Changes in Lease Accounting and Private Business Bankers' Credit Decisions. Accounting Perspectives 8 (1): 9-42.

Financial Accounting Standards Board (FASB) (1976). Statement of Financial Accounting Standards No. 13: Accounting for Leases. Norwalk, CT: FASB. 
Financial Accounting Standards Board (FASB) (2010). Exposure Draft: Proposed Accounting Standards Update - Leases (Topic 840). Norwalk, CT: FASB.

Financial Accounting Standards Board (FASB) (2011). News release, July 21, 2011: IASB and FASB announce intention to re-expose leasing proposals. Norwalk, CT: FASB.

G4+1 (1996). Accounting for Leases: A New Approach. London, UK: G4+1.

G4+1 (2000). Leases: Implementation of a New Approach. London, UK: G4+1.

Goodacre, A. (2001). The Potential Impact of Enforced Lease Capitalization in the UK Retail Sector. Working paper, University of Stirling.

Gosman, M., and Hanson, E. (2000). The Impact of Leasing on Lenders' Evaluations of Firms' Debt Levels. Commercial Lending Review 15 (3): 53-60.

Gritta, R., Lippman, E., and Chow, G. (1994). The Impact of the Capitalization of Leases on Airline Financial Analysis - An Issue Revisited. Logistics and Transportation Review 30 (2): 189-202.

Imhoff, E., Jr., Lipe, R., and Wright, D. (1991). Operating Leases: Impact of Constructive Capitalization. Accounting Horizons 5 (1): 51-63.

Imhoff, E. Jr., Lipe, R., and Wright, D. (1997). Operating Leases: Income Effects of Constructive Capitalization. Accounting Horizons 11 (2): 12-32.

Imhoff, E. Jr., and Thomas, J. (1988). Economic Consequences of Accounting Standards: the Lease Disclosure Rule Change. Journal of Accounting and Economics 10 (2): 277-310.

Kostolansky, J., and Stanko, B. (2011). The Joint FASB/IASB Lease Project: Discussion and Industry Implications._ Journal of Business \& Economics Research 9 (9): 29-35.

Lanfranconi, C., and Wiedman, C. (2000). If One Goes, Will the Other Follow? Operating Leases and Off-Balance-Sheet Accounting. Ivey Business Journal 64 (6): 61-5.

Lipe, R. (2001). Lease Accounting Research and the G4+1 Proposal. Accounting Horizons 15 (3): 299-310.

Nailor, H., and Lennard, A. (2000). Leases: Implementation of a New Approach. FASBFinancial Accounting Series Special Report. Norwalk, CT: FASB.

PricewaterhouseCoopers (PwC) (2009). The Future of Leasing: Research on Impact of Companies' Financial Ratios. New York, NY: PwC.

Ryan, S., Herz, R., Iannaconi, T., Maines, L., Palepu, K., Schipper, K., Schrand, C., Skinner, D., and Vincent, L. (2001). Evaluation of the Lease Accounting Proposed in G4+1 Special Report. Accounting Horizons 15 (3): 289-298.

Hong Kong Accounting Standards, http://www.hkicpa.org.hk/ebook/main.php. HKICPA Financial Statements of Fairwood Holdings Limited. 


\section{Macrothink}

International Journal of Accounting and Financial Reporting

ISSN 2162-3082 2013, Vol. 3, No. 1

http://www.fairwood.com.hk/jspwww/main.jsp.

Financial Statements of Café de Coral Holdings Limited. http://www.cafedecoral.com/web/ir/investor_report_a.htm.

\section{Copyright Disclaimer}

Copyright reserved by the author(s).

This article is an open-access article distributed under the terms and conditions of the Creative Commons Attribution license (http://creativecommons.org/licenses/by/3.0/). 